\title{
Coseismic deformation pattern of the Emilia 2012 seismic sequence imaged by Radarsat-1 interferometry
}

\author{
Christian Bignami ${ }^{1}$, Pierfrancesco Burrato ${ }^{2}$, Valentina Cannelli ${ }^{2}$, Marco Chini ${ }^{1}$, Emanuela Falcucci ${ }^{2}$, \\ Alessandro Ferretti ${ }^{3}$, Stefano Gori ${ }^{2}$, Christodoulos Kyriakopoulos ${ }^{1}$, Daniele Melini ${ }^{2}$, Marco Moro ${ }^{1}$, \\ Fabrizio Novali ${ }^{3}$, Michele Saroli ${ }^{1,4}$, Salvatore Stramondo ${ }^{1,{ }^{\star}}$, Gianluca Valensise ${ }^{2}$, Paola Vannoli ${ }^{2}$ \\ ${ }^{1}$ Istituto Nazionale di Geofisica e Vulcanologia, Centro Nazionale Terremoti, Roma, Italy \\ 2 Istituto Nazionale di Geofisica e Vulcanologia, Sezione Roma 1, Roma, Italy \\ 3 Tele-Rilevamento Europa (TRE) s.r.l., Milano, Italy \\ ${ }^{4}$ Università di Cassino e del Lazio Meridionale, Dipartimento di Ingegneria Civile e Meccanica (DICeM), Cassino (Frosinone), Italy
}

\author{
Article history \\ Received July 24, 2012; accepted August 20, 2012. \\ Subject classification: \\ Earthquake geology, Remote sensing, Tectonics, 2012 Emilia earthquake, SAR Interferometry, Seismogenic sources, Fault modeling.
}

\section{Introduction}

On May 20 and 29, 2012, two earthquakes of magnitudes 5.9 and $5.8\left(\mathrm{M}_{\mathrm{W}}\right)$, respectively, and their aftershock sequences hit the central Po Plain (Italy), about $40 \mathrm{~km}$ north of Bologna. More than 2,000 sizable aftershocks were recorded by the Istituto Nazionale di Geofisica e Vulcanologia (INGV; National Institute of Geophysics and Volcanology) National Seismic Network (http://iside.rm.ingv.it/). The sequence was generated by pure compressional faulting over blind thrusts of the western Ferrara Arc, and it involved a 50-km-long stretch of this buried outer front of the northern Apennines. The focal mechanisms of the larger shocks agree with available structural data and with present-day tectonic stress indicators, which show locally a maximum horizontal stress oriented ca. $\mathrm{N}$-S; i.e. oriented perpendicular to the main structural trends. Most of the sequence occurred between $1 \mathrm{~km}$ and $12 \mathrm{~km}$ in depth, above the local basal detachment of the outer thrust fronts of the northern Apennines.

We measured the surface displacement patterns associated with the mainshocks and some of the larger aftershocks (some of which had $\mathrm{M}_{\mathrm{W}}>5.0$ ) by applying the Interferometric Synthetic Aperture Radar (InSAR) technique to a pair of C-Band Radarsat-1 images. We then used the coseismic motions detected over the epicentral region as input information, to obtain the best-fit model fault for the two largest shocks.

\section{Geological and seismotectonic framework}

The region of the Italian peninsula struck by the MayJune 2012 seismic sequence is located at the outermost portion of the northern part of the Apennine chain (Figure 1). From a general point of view, the chain is a post-collisional belt, the formation of which is related to the complex interactions between the African and European plates and the Adria microplate. The 'backbone' of the chain consists of thrust planes and folds that started in the Oligocene, and that have displaced and superposed structural units pertaining to different Mesozoic-Cenozoic paleo-geographic domains. Compressional deformation results from the westward subduction of the Adriatic lithosphere and from its flexural retreat, causing the formation of compressional fronts migrating towards the $\mathrm{E}$ and NE, thus progressively affecting the Adriatic foreland [e.g. Malinverno and Ryan 1986, Patacca et al. 1990, Chiarabba et al. 2005, Basili and Barba 2007, Carminati et al. 2010, Cosentino et al. 2010, Molli et al. 2010]. For the northern Apennines, the literature describes the occurrence of several subsequent compressional deformation events that were marked by sedimentary sequences pertaining to foredeep and thrust-top basins that are progressively younger moving outwards [e.g. Ricci Lucchi 1986, Ciarapica and Passeri 1998, Cerrina Ferroni et al. 2004, Molli et al. 2010]. The Po Plain represents the present foredeep of both the northern Apennines and the southern Alps. Hence, the outermost Apennines thrust fronts are buried below the Pliocene-Quaternary marine and continental deposits that infill the Po Plain basin.

The frontal portion of the northern Apennines is organized in three complex systems of thrust-related folds: the Monferrato, the Emilian, and the Ferrara Arcs, from west to east, respectively. These buried folds have been extensively explored using seismic reflection lines and deep-well logs performed during oil exploration (Figure 1). Available subsurface data show a system of N-to-NE-verging blind thrusts and associated folds that have controlled the deposition of 


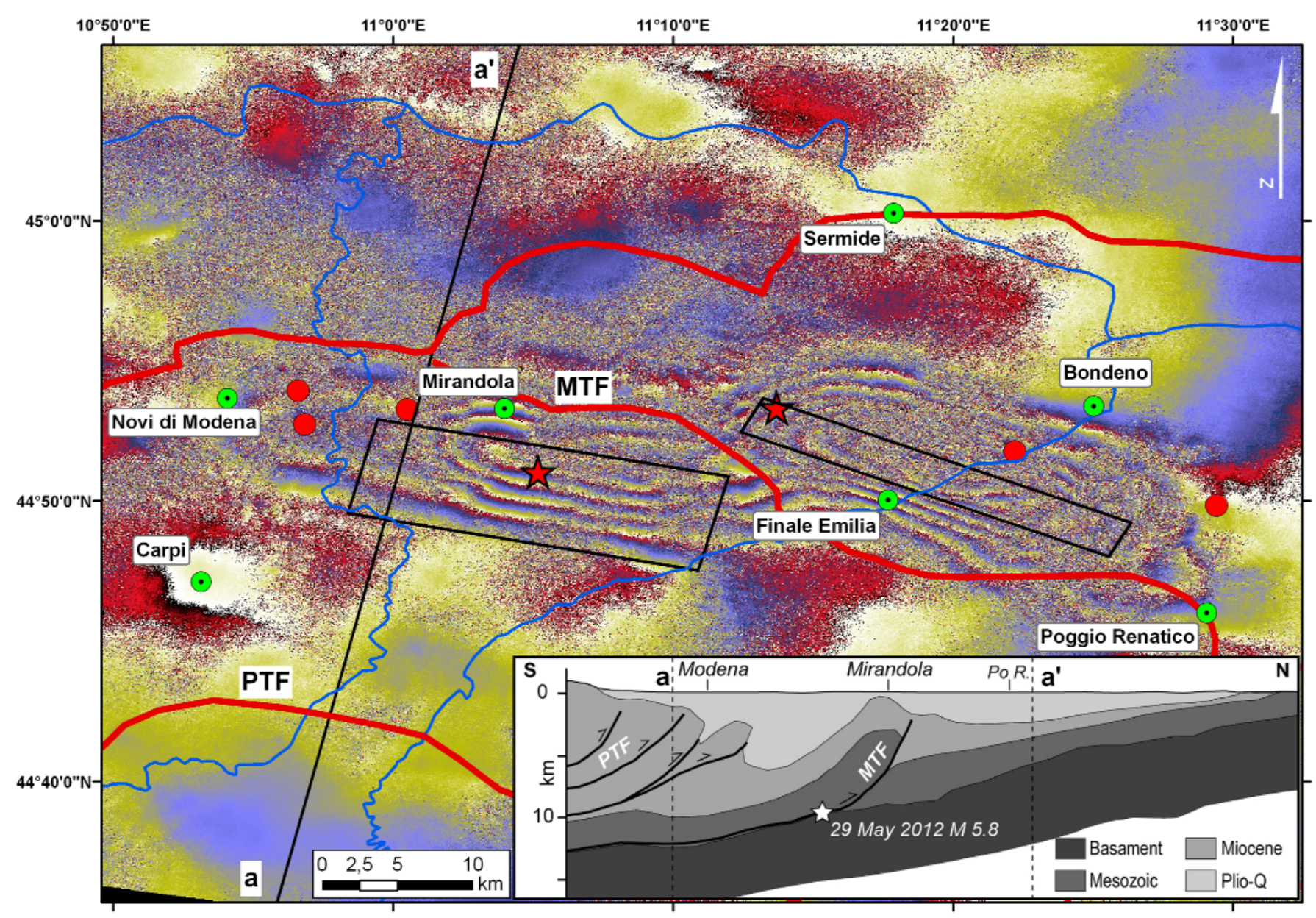

Figure 1. Radarsat-1 wrapped differential interferogram. Red stars, position of May 20 and 29 mainshocks; red lines, position of the main thrust fronts; black rectangles, surface projection of modeled faults. Inset: The N-S simplified geological section runs across the epicentral area of the May 29 mainshock, showing the geometry of the northern Apennines buried outer thrust fronts [redrawn from Cassano et al. 1986, and Fantoni and Franciosi 2010]. PTF: Pedeapenninic Thrust Front; MTF: Mirandola Thrust Front.

the syntectonic sedimentary wedges [e.g. Pieri and Groppi 1981, Scrocca et al. 2007, Stramondo et al. 2007, Picotti and Pazzaglia 2008, Toscani et al. 2009, and references therein]. The current activity of the frontal thrusts of the northern Apennine belt is testified by: 1) historic and instrumental seismicity, the latter characterized by focal mechanisms consistent with ongoing compression [e.g. Pondrelli et al. 2006]; 2) the influence of faulting and folding on the recent evolution of topography and of the drainage network [Burrato et al. 2003, Galadini et al. 2012]; 3) borehole breakouts, showing a regional stress field oriented perpendicular to the trend of the buried thrust fronts [Montone et al. 2012]; and 4) geodetic (global positioning system) data, indicating sustained shortening at about $2 \mathrm{~mm} / \mathrm{yr}$ over a 50-70-km-wide belt encompassing the Po Plain [Devoti et al. 2011].

As a whole, the May-June 2012 earthquake sequence fits well in the described tectonic setting, as it was caused by the activation of the above-mentioned Ferrara Arc, which resulted in earthquakes that occurred at the characteristic depth of the described fold structure and that had pure compressional focal solutions.

\section{Synthetic aperture radar data and processing}

Synthetic aperture radar (SAR) produces all-weather, day and night, high-resolution images of the Earth surface. These images provide useful information about the physical characteristics of the ground and of the vegetation canopy, such as surface roughness, soil moisture, tree height and biomass estimates. The combination of two or more SAR images of the same area makes it possible to generate surface change maps with high precision and resolution. Since 1992, the InSAR technique has been applied to study a number of natural processes, including earthquakes, volcanoes, glacier flows, landslides, and man-induced ground subsidence [Massonnet et al. 1993, Stramondo et al. 1999, Ferretti et al. 2001, Chini et al. 2010, Moro et al. 2011, Stramondo et al. 2011a].

In the present study, we processed two co-seismic C-band SAR images that were acquired by the Canadian Space Agency (CSA) RADARSAT-1 satellite. The images were collected during the satellite descending pass, with a viewing angle of $34^{\circ}$, as acquired on May 12 , just 8 days before the first shock, and on June 5, after the two main shocks and five aftershocks above $\mathrm{M}_{\mathrm{W}} 5.0$ (Table 1). The temporal baseline 
of the interferogram obtained was 24 days; the perpendicular baseline was $309 \mathrm{~m}$. The topographic contribution was removed from the interferometric phase using the digital elevartion model supplied by the Shuttle Radar Topographic Mission (SRTM) [Farr et al. 2007]. A Goldstein filter [Goldstein and Werner 1998] was applied to the differential interferogram obtained (Figure 1), to increase the signal-to-noise

\begin{tabular}{cccc}
\hline $\begin{array}{c}\text { Date } \\
(\text { yyyy /mm/dd) }\end{array}$ & $\begin{array}{c}\text { Latitude } \\
\left({ }^{\circ}\right)\end{array}$ & $\begin{array}{c}\text { Longitude } \\
\left({ }^{\circ}\right)\end{array}$ & $\mathrm{M}_{\mathrm{W}}$ \\
\hline $2012 / 05 / 20$ & 44.890 & 11.23 & 5.9 \\
$2012 / 05 / 20$ & 44.831 & 11.49 & 5.1 \\
$2012 / 05 / 29$ & 44.851 & 11.086 & 5.8 \\
$2012 / 05 / 29$ & 44.888 & 11.008 & 5.3 \\
$2012 / 05 / 29$ & 44.879 & 10.947 & 5.2 \\
$2012 / 05 / 29$ & 44.873 & 10.95 & 5.1 \\
$2012 / 06 / 03$ & 44.899 & 10.943 & 5.1 \\
\hline
\end{tabular}

Table 1. Locations of the earthquakes of the the May-June 2012 seismic sequence with $\mathrm{M}_{\mathrm{W}}>5.0$ ratio, thus allowing the unwrapping of the phase, to create the corresponding deformation map.

Figure 2 shows the surface displacement field along the line-of-sight. Most of the deformation detected corresponded to uplift, up to a maximum of ca. $200 \mathrm{~mm}$. The uplifted region is encircled by an area that experienced minor subsidence, which peaked at about $10 \mathrm{~mm}$ south of San Felice sul Panaro. This pattern is in good agreement with the expected kinematics of the buried tectonic structures (see, for example, Figure 5 in Vannoli et al. 2004). Overall the documented deformation pattern recorded a combination of the individual patterns associated with the two largest shocks of the sequence: the eastern portion of the deformation field is associated with the May 20 mainshock $\left(M_{W}\right.$ 5.9), while the western part is the result of the May 29 large aftershock $\left(M_{W}\right.$ 5.8). It is worth noting that the deformation associated with these two events overlaps. Additional, very minor, displacements $(<10 \mathrm{~mm})$ near to the western border of the interferogram (near Novi di Modena) might be due to the shocks with $\mathrm{M}_{\mathrm{W}}>5.0$ that occurred within the temporal span of the Radarsat-1 pair.

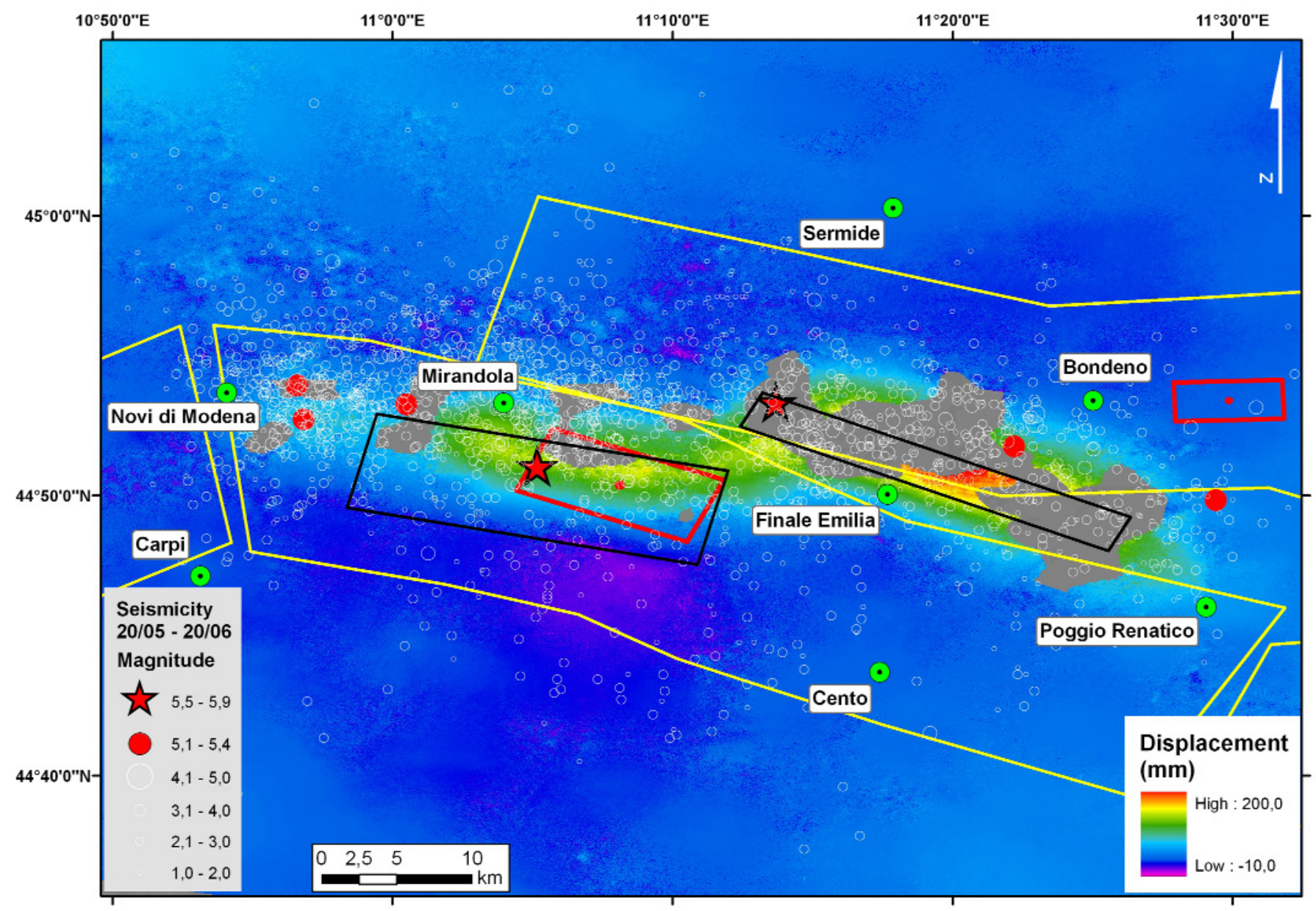

Figure 2. Radarsat-1 unwrapped differential interferogram. Red stars, position of May 20 and 29 mainshocks; black rectangles, surface projection of modeled faults; yellow polygons, surface projection of the ITCS050 ('Poggio Rusco-Migliarino') and ITCS051 ('Novi-Poggio Renatico') composite seismogenic sources; red polygons, surface projection of the ITIS107 ('Mirandola') and ITIS090 ('Ferrara') individual seismogenic sources of the DISS database (see text for further details). 


\section{Seismic source modeling}

We used the deformation field from InSAR measurements to derive a model for the rupture associated with the two mainshocks. Since the temporal baseline of SAR observations includes both mainshocks, the observed deformation represents a cumulative field that includes the effects of both of these events; we therefore need to simultaneously invert the parameters of both fault planes. We used the analytical expressions provided by Okada [1992] to estimate the deformation field for a given fault geometry, assuming uniform slip on both fault planes.

The best-fit fault parameters were estimated by minimizing the misfit between the observed and the modeled line-ofsight deformation through the adaptive simulated annealing algorithm [Ingber 1989]. To limit the computational load of the inversion procedure, we sampled the SAR deformation field according to a factor of 10 before starting the inversion procedure. The best-fit fault parameters for the two shocks are given in Table 2. Figure 3 shows the location and extent of

\begin{tabular}{lcc}
\hline \multirow{2}{*}{ Parameter } & \multicolumn{2}{c}{ Earthquake } \\
\cline { 2 - 3 } & May 20, 2012 & May 29, 2012 \\
\hline Fault center & $11.32^{\circ} \mathrm{E}, 44.85^{\circ} \mathrm{N}$ & $11.09^{\circ} \mathrm{E}, 44.84^{\circ} \mathrm{N}$ \\
Strike $\left(^{\circ}\right)$ & 115 & 102 \\
Dip $\left(^{\circ}\right)$ & 43 & 20 \\
Rake $\left(^{\circ}\right)$ & 90 & 95 \\
Slip (m) & 0.80 & 0.34 \\
Fault length & 19 & 16 \\
(along-strike) $(\mathrm{km})$ & & 6 \\
Fault width & 4 & \\
(along dip) $(\mathrm{km})$ & & 3.1 \\
Top depth $(\mathrm{km})$ & 4.0 & 4.2 \\
Center depth $(\mathrm{km})$ & 5.1 & 5.9 \\
Geodetic magnitude & 6.0 & \\
\hline
\end{tabular}

Table 2. Fault parameters for the May 20 and 29 earthquakes that resulted from the inversion of the SAR dataset. All of the parameters were left free in the inversion algorithm.
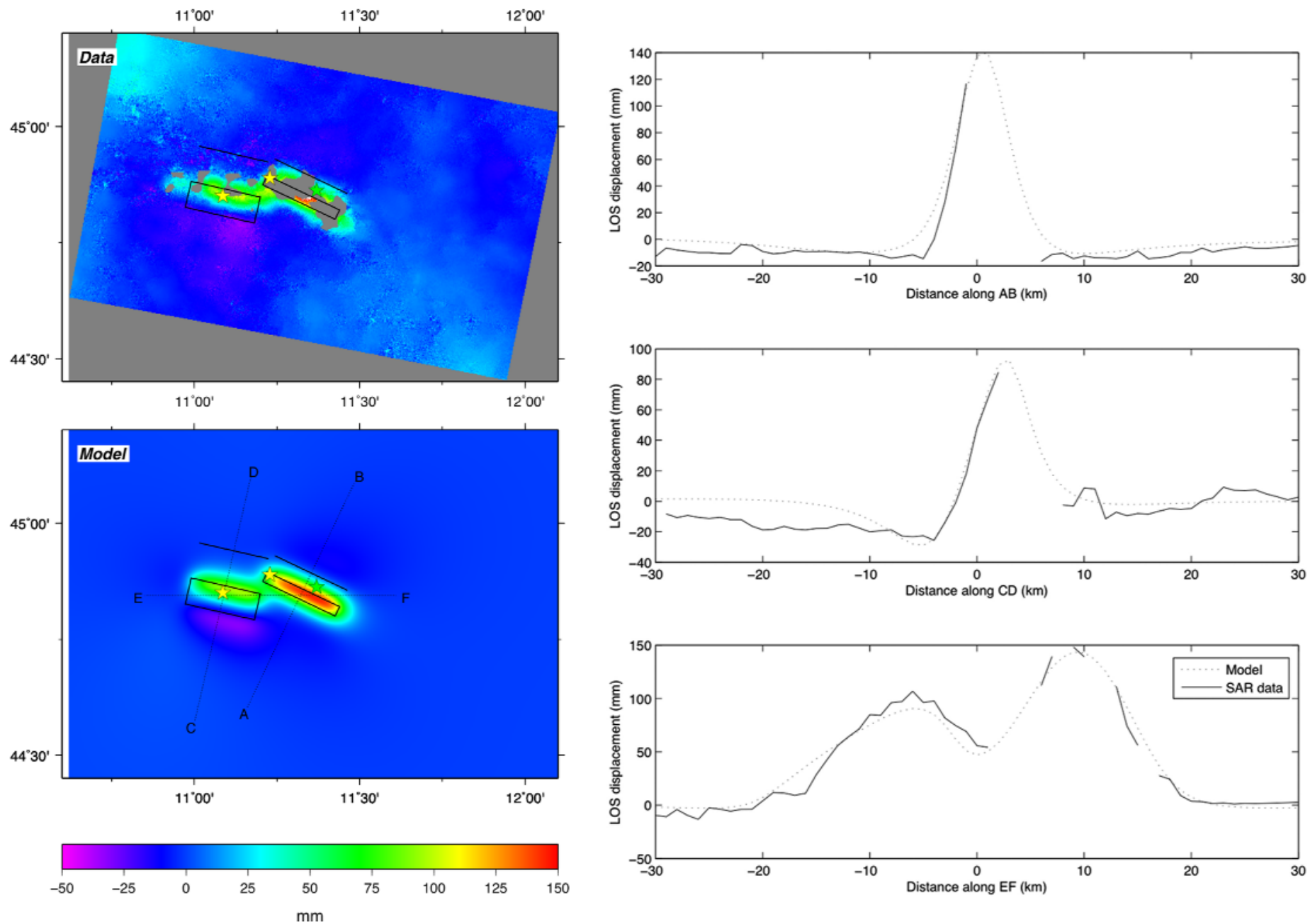

Figure 3. Left: Observed (top left) and modeled (bottom left) line-of-sight deformation fields. Rectangles, surface projection of the best-fit fault planes; yellow stars, epicentral locations of the May 20 and 29 events; green star, epicentral location of the May $20 \mathrm{M}_{\mathrm{W}} 5.1$ aftershock which occurred about 4 min after the mainshock. Right: Comparisons between the observed and modeled line-of-site deformation along the three profiles in bottom left panel. Profiles $\mathrm{AB}$ and $\mathrm{CD}$ are perpendicular to the strike direction of the May 20 and 29 model faults, respectively. Profile EF is alingned in the E-W direction to intersect both of the modeled faults and the area of maximum SAR-detected deformation. 
the two inferred sources and the modeled deformation field.

The nucleation of the May 20 mainshock falls near the western edge of the modeled plane, which suggests eastward propagation of the rupture. The retrieved focal parameters for this shock are consistent with the seismological estimates. This event, however, was followed after about 4 min by a $\mathrm{M}_{\mathrm{W}} 5.1$ aftershock that was located towards the eastern edge of the rupture zone, which effectively extended the rupture to the east. Similarly for the May 29 event, the location of which was near the center of the modeled plane. The best-fit strike and rake angles are consistent with the seismological estimates, while the resulting dip angle is somewhat smaller. The 'geodetic magnitudes' corresponding to the two events (6.0 and 5.9, respectively) are systematically larger than the seismological estimates. An excess of energy release that results from geodetic inversions with respect to purely seismological estimates has often been observed in the literature. Feigl et al. [2002] reported differences between geodetic and seismic moment of up to $60 \%$. Notwithstanding uncertainties in both the seismological and geodetic data and processing methods, this discrepancy is most likely due to the inclusion of interseismic, triggered aseismic, and post-seismic (afterslip and aftershock) deformation in the coseismic interferogram as a result of the longer measurement period.

\section{Discussion and conclusions}

We have used the InSAR technique to image the surface deformation due to the earthquake sequence that hit a portion of the Emilia-Romagna region, in the southeastern area of the Po Plain (northern Italy). We then modeled the observed strains by an inversion based on the standard Okada formulation. Due to its temporal baseline, which spans the two largest shocks of the sequence plus a few events above $\mathrm{M}_{\mathrm{W}}$ 5.0, our Radarsat-1 coseismic pair provided a comprehensive picture of the deformation due to the causative faults of the sequence. We would like to note that as shown by Stramondo et al. [2011b], the swath coverage ensured by a single frame of medium resolution SAR images provides a satisfactory view of the coseismic deformation field both in the case of a single M 6.5 to 7.0 earthquake and in the case of the activation of adjacent portions of a fault system with comparatively smaller earthquakes, as in the case of the MayJune 2012 sequence.

The modeled faults fit the N-to-NE-verging blind thrusts of the western Ferrara Arc both geometrically and kinematically. Their strike falls were in the range of $102^{\circ}$ to $115^{\circ}$, and they followed a gentle rotation of the arc, while the pure reverse faulting rake was consistent with the seismological ones. The model fault obtained for the May 20 event shows a dip of $43^{\circ}$ and a top depth of $4.0 \mathrm{~km}$, while the May 29 shock appears to have been caused by a more gently dipping and shallower thrust $\left(20^{\circ}\right.$, and top depth
$3.1 \mathrm{~km}$, respectively). Several studies have discussed the trade-off between InSAR data and faulting parameters [Dawson and Tregoning 2007, Weston et al. 2012]. Even though the measured surface displacement that results from a single earthquake also depends on the specific scenario [Feigl 2002], several studies have quantified the magnitude and depth ranges to which InSAR is most sensitive [Dawson and Tregoning 2007]. In the case of the May-June 2012 earthquakes, the modeled parameters are fully within these ranges, particularly for the InSAR-detected displacements and fault-top depth.

The May 20 and 29 earthquakes were somehow expected, based on pre-existing geological and structural knowledge. The geometrical parameters obtained for the model faults of the two main events show good fits with those of the ITCS050 'Poggio Rusco-Migliarino' (May 20) and ITCS051 'Novi-Poggio Renatico' (May 29) composite seismogenic sources (Figure 2) of the Database of Individual Seismogenic Sources (DISS) [DISS Working Group 2010, Basili et al. 2008]. The ongoing activity of these large thrusts was constrained by the DISS Working Group using geomorphic and subsurface geological data [e.g. Burrato et al. 2003].

The DISS database also lists a number of individual seismogenic sources; i.e. sources that are expected to rupture in future earthquakes at specific locations and of specific sizes. The geometrical paramaters of the individual seismogenic source listed as 'Mirandola' (ITCS051), from the name of the well-known Mirandola anticline, are surprisingly similar to those obtained for the source model of the May 29 rupture. Subsurface geological data were used to calculate the Late Pleistocene uplift rate of this source. Ciucci et al. [2002] first obtained a rate of $0.65 \mathrm{~mm} / \mathrm{y}$ of steady uplift of the anticline in the time range of $0.4 \mathrm{My}$ to the present, but their analysis did not take into consideration the effects of the differential compaction of sediments lying above the anticline itself. Scrocca et al. [2007] improved on these calculations by considering the differential compaction effect, and they obtained an uplift rate of $0.23 \mathrm{~mm} / \mathrm{y}$ for the same time interval. The 2012 seismic sequence activated a portion of the buried outer thrust fronts of the northern Apennines. However, historical seismicity located further south shows that the more internal thrust running at the mountain front is also active, testifying to the recent evolution of the thrust belt being characterized by an out-of-sequence deformation style.

Although the structural complexity of the region and the resolution of the available data did not allow the characteristics of the fault segments activated during the seismic sequence to be defined in particular detail, the results we have obtained shed new light on the seismotectonics of the region. This improved understanding will be crucial for the correct assessment of the earthquake potential of this densely populated portion of the Italian peninsula. 


\section{References}

Basili, R., and S. Barba (2007). Migration and shortening rates in the northern Apennines, Italy: implications for seismic hazard, Terra Nova, 19, 462-468.

Basili, R., G. Valensise, P. Vannoli, P. Burrato, U. Fracassi, S. Mariano, M.M. Tiberti and E. Boschi (2008). The Database of Individual Seismogenic Sources (DISS), version 3; summarizing 20 years of research on Italy's earthquake geology, Tectonophysics, 453, 20-43.

Burrato, P., F. Ciucci and G. Valensise (2003). An inventory of river anomalies in the Po Plain, northern Italy: evidence for active blind thrust faulting, Annals of Geophysics, 46 (5), 865-882.

Carminati, E., M. Lustrino, M. Cuffaro and C. Doglioni (2010). Tectonics, magmatism and geodynamics of Italy: what we know and what we imagine, In: M. Beltrando, A. Peccerillo, M. Mattei, S. Conticelli and C. Doglioni (eds.), The Geology of Italy, J. Virt. Explor., 36, paper 8.

Cassano E., L. Anelli, R. Fichera and V. Cappelli (1986). Pianura Padana, interpretazione integrata di dati geofisici e geologici, $73^{\circ}$ Congresso Società Geologica Italiana, Settembre/Ottobre 1986, Roma, Centro Stampa Agip.

Cerrina Ferroni, A., G. Ottria and A. Ellero (2004). The northern Apennines, Italy: geological structure and transpressive evolution, In: U. Crescentini, S. D'Offizi, S. Merlino and L. Sacchi (eds.), Geology of Italy, Special volume of the Italian Geological Society for IGC, Firenze, 15-32.

Chiarabba, C., L. Jovane and R. Di Stefano (2005). A new view of Italian seismicity using 20 years of instrumental recordings, Tectonophysics, 395, 251-268.

Chini, M., S. Atzori, E. Trasatti, C. Bignami, C. Kyriakopoulos, C. Tolomei and S. Stramondo (2010). The May 12, 2008, ( $\mathrm{M}_{\mathrm{w}}$ 7.9) Sichuan earthquake (China): multi-frame ALOS-PALSAR DInSAR analysis of coseismic deformation, IEEE Geosci. Remot. Sens. Lett., 7, 266-270.

Ciarapica, G., and L. Passeri (1998). Evoluzione paleogeografica degli Appennini, Atti Tic. Sc. Terra, 40, 233-390.

Cosentino, D., P. Cipollari, P. Marsili and D. Scrocca (2010). Geology of the central Apennines: a regional review, In: M. Beltrando, A. Peccerillo, M. Mattei, S. Conticelli and C. Doglioni (eds.), The Geology of Italy, J. Virt. Explor., 36, paper 11.

Dawson, J., and P. Tregoning (2007). Uncertainty analysis of earthquake source parameters determined from InSAR: A simulation study, J. Geophys. Res., 112, B09406; doi:10.1029/2007JB005209.

Devoti, R., A. Esposito, G. Pietrantonio, A.R. Pisani and F. Riguzzi (2011). Evidence of large-scale deformation patterns from GPS data in the Italian subduction boundary, Earth Planet. Sci. Lett., 311, 230-241.

DISS Working Group (2010). Database of Individual Seismogenic Sources (DISS), Version 3.1.1: A compilation of potential sources for earthquakes larger than M 5.5 in
Italy and surrounding areas; http: / / diss.rm.ingv.it/ diss / Fantoni, R., and R. Franciosi (2010). Tectono-sedimentary setting of the Po Plain and Adriatic Foreland, Rend. Fis. Accad. Lincei, 21, 197-209; doi:10.1007/s12210-010-0102-4.

Farr, T.G., P.A. Rosen, E. Caro, R. Crippen, R. Duren, S. Hensley, M. Kobrick, M. Paller, E. Rodriguez, L. Roth, D. Seal, S. Shaffer, J. Shimada, J. Umland, M. Werner, M. Oskin, D. Burbank and D. Alsdorf (2007). The shuttle radar topography mission, Rev. Geophys., 45, RG2 004.

Feigl, K.L. (2002). Estimating earthquake source parameters from geodetic measurements, International Handbook of Earthquake and Engineering Seismology, 81A, 607-620.

Ferretti, A., C. Prati and F. Rocca (2001). Permanent scatterers in SAR interferometry, IEEE Trans. Geosci. Remot. Sens., 39, 8-20.

Galadini, F., E. Falcucci, P. Galli, B. Giaccio, S. Gori, P. Messina, M. Moro, M. Saroli and A. Sposato (2012). Time intervals to assess active and capable faults for engineering practices in Italy, Engineering Geology, 139/140, 50-65.

Goldstein, R.M., and C.L. Werner (1998). Radar interferogram filtering for geophysical applications, Geophys. Res. Lett., 25, 4035-4038.

Ingber, L. (1989). Very fast simulated re-annealing, Math. Comput. Modell., 12, 967-993.

Malinverno, A., and W.B.F. Ryan (1986). Extension in the Tyrrhenian Sea and shortening in the Apennines as result of arc migration driven by sinking of the lithosphere, Tectonics, 5, 227-245.

Massonnet, D., M. Rossi, C. Carmona, F. Adragna, G. Peltzer, K. Feigl and T. Rabaute (1993). The displacement field of the Landers earthquake mapped by radar interferometry, Nature, 364, 138-142.

Molli, G., L. Crispini, P. Mosca, F. Piana and L. Federico (2010). Geology of the western Alps-northern Apennine junction area: a regional review, In: M. Beltrando, A. Peccerillo, M. Mattei, S. Conticelli and C. Doglioni (eds.), The Geology of Italy, J. Virt. Explor., 36, paper 9.

Montone, P., M.T. Mariucci and S. Pierdominici (2012). The Italian present-day stress map, Geophys. J. Int., 189, 705-716.

Moro, M., M. Chini, M. Saroli, S. Atzori, S. Stramondo and S. Salvi (2011). Analysis of large, seismically induced, gravitational deformations imaged by high resolution COSMO-SkyMed SAR, Geology, 39, 527-530.

Okada, Y. (1992). Internal deformation due to shear and tensile faults in a half space, B. Seismol. Soc. Am., 82, 1018-1040.

Patacca, E., R. Sartori and P. Scandone (1990). Tyrrhenian basin and Apenninic arcs: kinematic relations since Late Tortonian times, Memorie della Società Geologica Italiana, 45, 425-451.

Picotti, V., and F.J. Pazzaglia (2008). A new active tectonic model for the construction of the northern Apennines 
mountain front near Bologna (Italy), J. Geophys. Res., 113, B08412.

Pieri, M., and G. Groppi (1981). Subsurface geological structure of the Po plain, Italy, Consiglio Nazionale delle Ricerche, Agip, Progetto Finalizzato Geodinamica, Pubblicazione n. 414, Roma.

Pondrelli, S., S. Salimbeni, G. Ekstrom, A. Morelli, P. Gasperini and G. Vannucci (2006). The Italian CMT dataset from 1977 to the present, Phys. Earth Planet. Interior, 159, 286-303.

Ricci Lucchi, F. (1986). The Oligocene to recent foreland basins of the northern Appennines, in Foreland Basins, edited by P.A. Allen and P. Homewood, IAS Special Publication, Oxford, Blackwell Scientific, 8, 105-139.

Scrocca, D., E. Carminati, C. Doglioni and D. Marcantoni (2007). Slab retreat and active shortening along the central-northern Apennines, In: O. Lacombe, J. Lavé, F. Roure and J. Verges, Thrust belts and Foreland Basins: from fold kinematics to hydrocarbon systems, Springer, 471-487.

Stramondo, S., M. Tesauro, P. Briole, E. Sansosti, S. Salvi, R. Lanari, M. Anzidei, P. Baldi, G. Fornaro, A. Avallone, M.F. Buongiorno, G. Franceschetti and E. Boschi, (1999). The September 26, 1997 Colfiorito, Italy, earthquakes: modeled coseismic surface displacement from SAR Interferometry and GPS, Geophys. Res. Lett., 26, 883-886.

Stramondo S., M. Saroli, C. Tolomei, M. Moro, F. Doumaz, A. Pesci, F. Loddo, P. Baldi and E. Boschi (2007). Surface movements in Bologna (Po Plain, Italy) detected by multitemporal DInSAR, Remote Sens. Environ., 110, 304-316.

Stramondo, S., C. Kyriakopoulos, C. Bignami, M. Chini, D. Melini, M. Moro, M. Picchiani, M. Saroli and E. Boschi (2011a). Did the September 2010 (Darfield) earthquake trigger the February 2011 (Christchurch) event?, Scientific Reports, 1, 98.

Stramondo, S., M. Chini, C. Bignami, S. Salvi and S. Atzori (2011b). X- C- L-Band DInSAR investigation of the April 6, 2009, Abruzzi earthquake, IEEE Geosci. Remote Sens. Lett., 8, 49-53.

Toscani, G., P. Burrato, D. Di Bucci, S. Seno and G. Valensise (2009). Plio-Quaternary tectonic evolution of the northern Apennines thrust fronts (Bologna-Ferrara section, Italy): seismotectonic implications, Ital. J. Geosci., 128, 605-613.

Vannoli, P., R. Basili and G. Valensise (2004). New geomorphic evidence for anticlinal growth driven by blindthrust faulting along the northern Marche coastal belt (central Italy), J. Seismol., 8, 297-312.

Weston, J.A., M.G. Ferreira and G.J. Funning (2012). Systematic comparisons of earthquake source models determined using InSAR and seismic data, Tectonophysics, 532-535, 61-81.
*Corresponding author: Salvatore Stramondo, Istituto Nazionale di Geofisica e Vulcanologia, Centro Nazionale Terremoti, Roma, Italy; email: salvatore.stramondo@ingv.it.

C 2012 by the Istituto Nazionale di Geofisica e Vulcanologia. All rights reserved. 